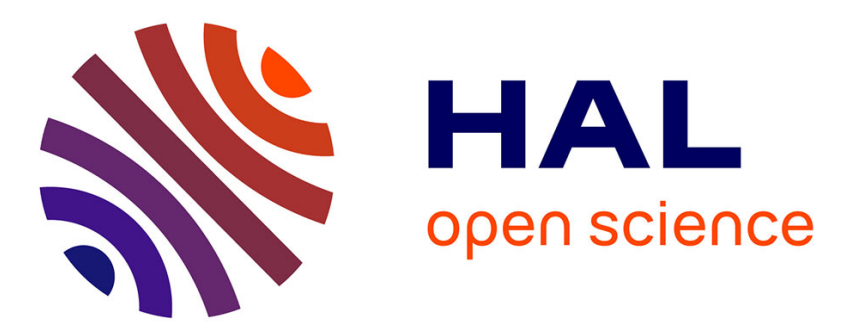

\title{
Causes of Enhanced Bromine Levels in Alpine Ice Cores During the 20th Century: Implications for Bromine in the Free European Troposphere
}

Michel Legrand, J. R Mcconnell, S. Preunkert, N. J Chellman, M. M Arienzo

\section{- To cite this version:}

Michel Legrand, J. R Mcconnell, S. Preunkert, N. J Chellman, M. M Arienzo. Causes of Enhanced Bromine Levels in Alpine Ice Cores During the 20th Century: Implications for Bromine in the Free European Troposphere. Journal of Geophysical Research: Atmospheres, 2021, 126 (8), 10.1029/2020JD034246 . hal-03426746

\author{
HAL Id: hal-03426746 \\ https://hal.science/hal-03426746
}

Submitted on 12 Nov 2021

HAL is a multi-disciplinary open access archive for the deposit and dissemination of scientific research documents, whether they are published or not. The documents may come from teaching and research institutions in France or abroad, or from public or private research centers.
L'archive ouverte pluridisciplinaire HAL, est destinée au dépôt et à la diffusion de documents scientifiques de niveau recherche, publiés ou non, émanant des établissements d'enseignement et de recherche français ou étrangers, des laboratoires publics ou privés. 


\section{Causes of enhanced bromine levels in Alpine ice cores during the $20^{\text {th }}$ century: Implications for bromine in the free European troposphere}

\section{Legrand ${ }^{1,2}$, J. R. McConnell ${ }^{3}$, S. Preunkert ${ }^{1}$, N. J. Chellman ${ }^{3}$, and M. Arienzo ${ }^{3}$}

${ }^{1}$ IGE, Institut des Géosciences de l'Environnement, UMR 5001, CNRS, Université Grenoble Alpes, Grenoble, France.

${ }^{2}$ Now at LISA, Laboratoire Interuniversitaire des Systèmes Atmosphériques, UMR CNRS 7583, Université Paris-Est-Créteil, Université de Paris, Institut Pierre Simon Laplace (IPSL), Créteil, France

${ }^{3}$ Division of Hydrologic Sciences, Desert Research Institute, Reno, Nevada, USA.

Corresponding author: Michel Legrand (michel.legrand@lisa.ipsl.fr )

\section{Key Points:}

- Alpine ice revealed a two-fold increase in total bromine, mainly after 1950

- Bromine trends in alpine ice attributed to aerosol from leaded-gasoline use and reactive gases from anthropogenic $\mathrm{CH}_{3} \mathrm{Br}$ emissions

First published in Journal of Geophysical Research: Atmospheres on 2021-04-7. Reference:

Legrand, M., McConnell, J. R., Preunkert, S., Chellman, N. J. and Arienzo, M. : Causes of enhanced bromine levels in Alpine ice cores during the 20 century : Implications for bromine in the free European troposphere. - Journal of Geophysical Research. DOI : https://doi.org/ 10.1029/2020JD034246

URL of original publication:

https://agupubs.onlinelibrary.wiley.com/doi/full/10.1029/2020JD034246 


\section{Abstract}

Total bromine $(\mathrm{Br})$ was investigated in seasonally-resolved alpine ice cores covering the $20^{\text {th }}$ century. Results revealed increased $\mathrm{Br}$ concentrations in summer (from $0.7 \mathrm{ng} \mathrm{g}^{-1}$ in the late 1940s to $1.6 \mathrm{ng} \mathrm{g}^{-1}$ in the mid 1970s), followed by a slight decrease to $1.25 \mathrm{ng} \mathrm{g}^{-1}$ during the last decade of the $20^{\text {th }}$ century. In winter, a more moderate increase was observed from prior to 1950 $\left(0.35 \mathrm{ng} \mathrm{g}^{-1}\right)$ to the $1970-2000$ period $\left(\sim 0.50 \mathrm{ng} \mathrm{g}^{-1}\right)$. Measurements of lead suggest that $\sim 75 \%$ of the bromine increase in summer alpine ice between 1930-1950 and 1965-1985 was from bromine-containing aerosol $(\mathrm{PbBrCl})$ emitted during combustion of leaded gasoline. This contribution decreased to $\sim 27 \%$ in 2000 following the large decrease of lead additive content in gasoline used in western Europe. Summer ice bromine concentrations, not related to $\mathrm{PbBrCl}$ aerosol (denoted $\mathrm{Br}_{\mathrm{y}}{ }^{*}$ ), increased by $40 \%$ from the late 1940s to the 1990-2000 decade. In winter, the contribution of leaded-gasoline aerosol to total bromine levels was weaker than in summer, with the winter bromine trend mainly caused by enhanced $\mathrm{Br}_{\mathrm{y}} *$ levels $(\sim 40 \%)$ after 1950. These $\mathrm{Br}_{\mathrm{y}}$ * variations in glacial ice are discussed in terms of past atmospheric reactive bromine $\left(\mathrm{Br}_{\mathrm{y}}\right)$ changes in the European troposphere including anthropogenic $\mathrm{CH}_{3} \mathrm{Br}$ emissions and transport from the stratosphere.

\section{Plain Language Summary}

Bromine chemistry plays an important role in tropospheric chemistry, influencing the levels of ozone and several other key atmospheric species including $\mathrm{HO}_{\mathrm{x}}$ and $\mathrm{NO}_{\mathrm{x}}$ radicals. Measurements conducted in alpine ice cores spanning the $20^{\text {th }}$ century showed a doubling of total bromine from the late 1940s to the 1980-1990s. This first identification of changes in bromine in ice cores extracted outside polar regions, where ice records are strongly influenced by sea-ice process, is of interest for bromine chemistry model simulations of past, present, and future tropospheric ozone changes in the mid-latitudes. It is shown that alpine ice core records contain information on past bromine particles emitted by leaded-gasoline combustion, revealing the rapid growth of these anthropogenic emissions from 1950 to 1975 and the subsequent decline caused by the reduced use of lead additive in gasoline in western Europe. In addition to changes in the aerosol component, the remaining part of the observed increase of total bromine in alpine ice is attributed to enhanced levels of inorganic bromine gaseous species resulting from anthropogenic emissions including $\mathrm{CH}_{3} \mathrm{Br}$ (fumigation).

\section{Introduction}

Aside from bromine aerosols directly emitted into the atmosphere by natural sources (sea-salt and mineral dust) and anthropogenic sources (primarily $\mathrm{PbBrCl}$ from combustion of leaded-gasoline (Habibi, 1973)), most inorganic bromine atmospheric species are gases. Among these gases, bromine radicals $(\mathrm{Br}$ and $\mathrm{BrO})$ are catalysts for ozone destruction and influence the budget of $\mathrm{HO}_{\mathrm{x}}$ and $\mathrm{NO}_{\mathrm{x}}$ radicals. The impact of halogens on tropospheric chemistry first emerged as an issue from observation of sudden decreases in surface ozone in spring both in the Arctic (Bottenheim et al., 1986) and coastal Antarctica (Friess et al., 2004). More recent observational studies have shown the importance of reactive bromine species in the present-day global troposphere (Volkamer et al., 2015). At the global scale, the role of bromine chemistry has been assessed by numerous transport-chemistry model simulations (Ordonez et al., 2012;

61 Parrella et al., 2012; Saiz-Lopez et al., 2012; Sherwen et al., 2017; von Glasow et al., 2004; Yang et al., 2005), although confidence in these models has been limited by the paucity of 
bromine species observations. Also, there are still uncertainties in knowledge of tropospheric bromine chemistry, particularly heterogeneous chemistry (Simpson et al., 2015).

At present, the main sources of inorganic bromine gases ( $\mathrm{Br}_{\mathrm{y}}$ defined as the sum of $\mathrm{Br}$, $\mathrm{BrO}, \mathrm{HBr}, \mathrm{HOBr}, \mathrm{BrNO}_{2}, \mathrm{BrNO}_{3}, \mathrm{Br}_{2}, \mathrm{IBr}$, and $\mathrm{BrCl}$ ) in the troposphere are (1) photochemical decomposition of organobromines $\left(\mathrm{CHBr}_{3}, \mathrm{CH}_{2} \mathrm{Br}_{2}\right.$, and $\left.\mathrm{CH}_{3} \mathrm{Br}\right)$, (2) release of bromine from sea-salt aerosol, and (3) transport from the stratosphere where $\mathrm{Br}_{\mathrm{y}}$ is produced from photochemical decomposition of organobromines and halons (Liang et al., 2014). $\mathrm{CH}_{2} \mathrm{Br}_{2}$ and $\mathrm{CHBr}_{3}$ are of marine biogenic origin, while $\mathrm{CH}_{3} \mathrm{Br}$ has both natural (ocean, biomass burning, and marshes) and anthropogenic (fumigation and leaded gasoline combustion) sources (Reeves, 2003). The relative contribution of bromine release from sea-salt to the $\mathrm{Br}_{\mathrm{y}}$ budget is spatially dependent, with a large contribution in the marine-boundary layer and a weakened, but still significant contribution (25\%) in the free troposphere (Parrella et al., 2012; Schmidt et al., 2016; Yang et al., 2005). The impact of sea-salt debromination on the level of reactive bromine species is, however, still a subject of debate because of uncertainties in the uptake of $\mathrm{HBr}$ on sea-salt aerosol and of HOBr by aerosols (Zhu et al., 2019).

More uncertain is the past budget of $\mathrm{Br}_{\mathrm{y}}$. For instance, the budget of $\mathrm{CH}_{3} \mathrm{Br}$, an important precursor of $\mathrm{Br}_{\mathrm{y}}$ in the free troposphere, is still uncertain for both the present-day and prior anthropogenic emissions (Kurylo \& Rodriguez, 1999; Reeves, 2003). Even for emissions from leaded-gasoline combustion that reached a maximum around 1975 (Thomas et al., 1997), there is debate on the fraction of emissions that is emitted (in addition to $\mathrm{PbBrCl}$ aerosol) as $\mathrm{CH}_{3} \mathrm{Br}$, with values ranging from 0.1 to $25 \%$ (Reeves, 2003). Recent acidification of the atmosphere may have modulated the intensity of sea-salt debromination, at least in some regions of the world; but up to now this effect has not been quantified. This lack of model sea-salt debromination simulations and change through time, together with previously discussed uncertainties on the role of this $\mathrm{Br}_{\mathrm{y}}$ source on bromine radicals concentrations, have hampered the ability of models addressing past changes of bromine to simulate ozone changes (Parrella et al., 2012; Sherwen et al., 2016) to consider possible past changes of sea-salt debromination in response to recent acidification of the atmosphere caused by growing $\mathrm{SO}_{2}$ and $\mathrm{NO}_{\mathrm{x}}$ emissions.

To assess past changes in $\mathrm{Br}_{\mathrm{y}}$ chemistry and subsequent contributions to tropospheric ozone changes, ice cores provide an option for improved scientific understanding. Indeed, most inorganic bromine gases present in the atmosphere are highly water soluble and, as bromine aerosol, are wet and dry deposited. Investigating total bromine in the ice provides a means to relate bromine aerosol and major gaseous $\mathrm{Br}_{\mathrm{y}}$ species, including $\mathrm{HOBr}, \mathrm{BrONO}_{2}, \mathrm{HBr}$, and $\mathrm{BrO}$ (Schmidt et al., 2016; Sherwen et al., 2016) in the past. Some bromine species are, however, reversibly trapped in snow and may be remobilized after snow deposition (Abbatt, 2013; Jacobi et al., 2012) particularly at low snowfall polar sites. The effects of reversible deposition have to be carefully considered when inferring past atmospheric bromine changes from ice-core records.

Until now, most ice core studies of total bromine were conducted in polar ice (Maselli et al., 2017). Except at sea level, bromine deposited in these high-latitude remote regions is expected to mainly originate from $\mathrm{Br}_{\mathrm{y}}$, whereas bromine aerosol emitted from both natural and anthropogenic sources should be insignificant or weak. In this way, Maselli et al. (2017) estimated that leaded-gasoline combustion represented less than $10 \%$ of total bromine in central Greenland ice deposited in the 1970s. In high-latitude regions, Bry should be related to debromination of sea-salt aerosol produced over the open ocean and sea ice (Yang et al., 2008; Spolaor et al., 2013; Legrand et al., 2016; Spolaor et al., 2016). It was discovered recently that 
oceanic emissions of organic bromine compounds, that represent an important source of $\mathrm{Br}_{\mathrm{y}}$ in the tropics (Saiz-Lopez et al., 2007), also occur in winter at high latitudes through sea-ice related processes (Abrahamson et al., 2018). Polar ice-core records are thus particularly suitable for examining $\mathrm{Br}_{\mathrm{y}}$ budgets at high-latitudes with respect to sea-ice conditions.

The atmospheric significance of bromine changes recorded in non-polar ice has not yet been explored. The generally high snow accumulation rates typical of non-polar sites strongly limits remobilization of bromine after snow deposition. Because of their proximity to industrialized areas, ice cores extracted from non-polar sites may be useful for reconstructing impacts of human activities on bromine budgets over continental source regions. In the Alps for instance, atmospheric transport-model simulations show that emissions from countries located within $\sim 1000 \mathrm{~km}$ of the Alps (i.e., France, Italy, Spain, Switzerland, and Germany) are the largest contributors of impurities trapped in Alpine ice (Fagerli, et al., 2007; Legrand et al., 2020; Arienzo et al. 2021). Compared to polar regions, we may expect a larger contribution of bromine aerosol (dust and $\mathrm{PbBrCl}$ from leaded-gasoline, for instance) at mid-latitude glacier sites to total bromine present in ice. Concerning $\mathrm{Br}_{\mathrm{y}}$, a larger contribution of organic precursors with respect to sea-salt debromination is expected at mid-latitude sites including $\mathrm{CH}_{3} \mathrm{Br}$ for which an anthropogenic trend is expected.

Here we report total bromine measurements made in ice cores drilled at the Col du Dome (CDD) alpine site located near the Mont Blanc summit (French Alps). A seasonally resolved bromine ice record was obtained covering continuously the 1930-2000 time-period with limited data from pre-industrial times (prior to 1850 ) to 1930. After examining the impact of sporadic events (volcanic eruptions and Saharan dust events), we estimated using ancillary measurements of lead the contribution of aerosol produced by leaded-gasoline combustion to observed past changes of total bromine in ice. We also considered the remaining part of total bromine not related to aerosol and its increase in the alpine ice after 1950 in terms of changing sources of inorganic bromine gases including $\mathrm{CH}_{3} \mathrm{Br}$.

\section{Site, Ice Core Dating, and Methods}

To investigate changes of bromine from the pre-industrial times to the end of the $20^{\text {th }}$ century, we made measurements on three ice cores extracted at the CDD site (4250 m above sea level). The C10 core (126 m long) was drilled in 1994, the CDK core (124 m long) in 2004, and the CDM core (140 m long) in 2012, with the CDK drilling site less than $50 \mathrm{~m}$ from the colocated C10 and CDM sites. Initially dedicated to the study of organic carbon, halogens (bromine and iodine), as well as various metals, the analysis were restricted to parts of the cores with ice (a non-porous material with density $>0.83 \mathrm{~g} \mathrm{~cm}^{-3}$ ) and dense firn (a porous material with density $>0.70 \mathrm{~g} \mathrm{~cm}^{-3}$ ). The reason is that, in addition to significant contamination of firn by organics (Legrand et al., 2013), Legrand et al. (2018) showed that iodine could escape from more porous firn after core extraction, either during storage or melting of samples prior to analysis.

To extend the time covered by the ice portion of the C10 core to years after 1985, the upper ice sections of the CDM core covering 1979 to 1999 also were used to provide a composite C10-CDM record covering the 1890-2000 period. As a result of a problem during analysis of the $\mathrm{C} 10$ core, no bromine data are available along a $4 \mathrm{~m}$ section covering 1894 to 1923 (explained below). To increase documentation of layers deposited during the first half of the $20^{\text {th }}$ century, we also investigated ice samples from the CDK ice core. In addition, analysis was conducted on the basal CDK ice to document pre-industrial levels. 
The upper sections of the CDD ice cores were dated by annual-layer counting, primarily using pronounced seasonal variations in ammonium concentration (summer-to-winter ratio exceeding 10; Fig. 1). Following Preunkert et al. (2000), the boundary of the winter half year has been identified by at least three consecutive samples having an ammonium level lower than $10 \mathrm{ng} \mathrm{g}^{-1}$. To derive mean seasonal cycles (Fig. 1), summer and winter layers were divided into 6 equal parts and the monthly time scale reported in Figure 1 was determined by matching the mean temperature observed at $2472 \mathrm{~m}$ elevation in the Alps to the mean $\delta \mathrm{D}$ (deuterium) seasonal cycle in the CDD ice (Preunkert et al., 2000).

Annual ice layer thickness (ILT) at CDD decreases down the length of the core from 1.6 meter of water equivalent (mwe) between 1970 and 2000 to 0.46 mwe between 1930 and 1950 (see Fig. S3 in the SI in Legrand et al. (2018)). Such a decrease with depth is related to ice thinning and wind erosion upstream the drill site. The latter leads to greater thinning of winter layers with depth at CDD, with winter layer thickness decreasing by almost by a factor 5 compared to 3 for summer layers from 1970-2000 to 1930-1950 (Legrand et al. 2018; Preunkert et al., 2000). Although winter layers can be identified back to 1890, for some years the boundary of the winter half-year defined as at least three consecutive samples having an ammonium level lower than 10 ng $\mathrm{g}^{-1}$ was not reached; prior to 1930 only a few winter half-year means were calculated. The resulting C10 chronology was assigned an age of 1890 at $118.3 \mathrm{~m}$ (Legrand et al., 2018). Prior to 1890 , almost no winter snow was preserved because of seasonal changes in net snow deposition upstream the coring site (i.e., snow erosion by wind in winter), but the age range of the lower meters of the C10 core was estimated to cover 1830 to 1890 (possibly 1640 to 1890) at $125 \mathrm{~m}$ depth (i.e., beyond the onset of the pre-industrial period in 1850) (Legrand et al., 2020).

A chronology for the basal CDK ice was established by ${ }^{14} \mathrm{C}$ analysis of particulate organic carbon indicating the bottommost ice spans the period 3050 before Common Era (BCE) to $\sim 950 \mathrm{CE}$ (Preunkert et al., 2019). These data also were used to examine pre-industrial levels back to antiquity.

These CDD ice cores previously were investigated by subsampling pieces of firn and ice with subsequent analysis by ion chromatography (IC) at the Institut des Géosciences de l'Environnement (IGE) permitting investigation of long-term major ion trends including for sulfate, nitrate, ammonium, and calcium (Preunkert \& Legrand, 2013). In the present study, CDD ice cores were analysed using the continuous flow ice core analytical system at the Desert Research Institute (DRI) Ultra Trace Chemistry Laboratory. Longitudinal core samples (section of $3.3 \mathrm{~cm} \times 3.3 \mathrm{~cm}$ ) were melted sequentially, with the meltwater stream split into three regions. Bromine and co-analysed species including lead $(\mathrm{Pb})$, and cerium $(\mathrm{Ce})$ were measured in the meltwater from the innermost ring (10\% of the sample cross section) by using two inductively coupled plasma mass spectrometers (ICP-MS, Thermo Scientific Element 2 high-resolution with PFA-ST concentric Teflon ${ }^{\mathrm{TM}}$ nebulizer [electro-spray ionization - ESI]) operating in parallel. Working conditions were described in Maselli et al. (2017) and McConnell et al. (2019). The detection was taken as three times the standard deviation of the blank $\left(0.06 \mathrm{ng} \mathrm{g}^{-1}\right.$ for $\mathrm{Br}, 0.0004$ $\mathrm{ng} \mathrm{g}^{-1}$ for $\mathrm{Pb}$, and $0.0003 \mathrm{ng} \mathrm{g}^{-1}$ for $\mathrm{Ce}$ ). Measurement of total $\mathrm{Ce}$ is influenced by sample acidification times, recovery for Ce typically being found to be $\sim 60 \%$ (McConnell et al., 2018). We have therefore scaled the continuous Ce measurements by 1.66 to compensate for underrecovery during continuous Ce analyses. For bromine, no under-recovery of measurements is expected. During analysis of the C10 cores, from 113.7 to $117.85 \mathrm{~m}$ depth (i.e., 1922 to 1894 ), clogging in the line of the ICP-MS that measures bromine occurred resulting in no accurate 
bromine data for this depth interval. Among species that were measured in this line, $\mathrm{Pb}$ and $\mathrm{Ce}$ were, however, also analysed on the second ICP-MS line.

In this work, we used $\mathrm{Pb}$ data to estimate anthropogenic bromine emissions related to leaded-gasoline emissions. With this aim, we calculated the non-crustal $\mathrm{Pb}$ fraction $(\mathrm{ncPb})$, which is mainly related to $\mathrm{Pb}$ anthropogenic emissions including leaded-gasoline emissions. Following Legrand et al. (2020), the ncPb concentrations were calculated by subtracting from the total $\mathrm{Pb}$ concentrations the crustal fraction calculated from $\mathrm{Ce}$ measurements (corrected for under-recovery) and the mean sediment $\mathrm{Pb} / \mathrm{Ce}$ ratio (0.23, Bowen (1966)). On average between 1890 and 2000, the soil contribution to Pb levels of CDD ice remained on the order of $1 \%$.

\section{Ice Core Data Presentation}

Evaluation of long-term chemical records extracted from the small-scale Col du Dome glacier have to account for systematic changes in snow deposition characteristic of the area upstream from the drill site. As discussed in section 2, the net annual ice layer thickness decreases down the length of the CDD ice-cores due to ice thinning and wind erosion upstream the drill site. Furthermore, winter layers generally thin with depth relative to summer layers in relation with a lack of preservation of blowing winter snow (Preunkert et al., 2000). Since most chemical species exhibit a pronounced winter-to-summer contrast (Fig. 1), such a change with depth-of-snow accumulation conditions induces a non-atmospheric effect in CDD ice chemical records. Instead of examining the annual (or multi-annual) averaged values, it is thus more appropriate to separately examine summer and winter trends.

Using the midwinter minimum of ammonium concentration in Alpine snow we determined half-year summer and winter means from 1890 to 1999. Mean summer and winter bromine concentrations measured in the ice from 1890 to 2000 are shown in Fig. 2. More than $60 \%$ of the 1948 summer layer was not analysed and the half-summer 1948 value was thus not considered. Figure 2 indicates that, in addition to an overall increase in bromine concentrations over the $20^{\text {th }}$ century, the CDD ice records exhibit significant year-to-year variability, with high summer values in 1928, 1955, 1989, and 2000 and low values in 1968, 1983, 1991, and 1995. Previous EMEP (European Monitoring and Evaluation Programme) transport-chemistry have shown that concentrations of ammonium and sulfate at CDD are significantly modulated within a factor of 2 to 3 by the meteorological variability (Fagerli et al., 2007). As discussed in Text S2, it appears that it is also the case with bromine although with the noticeable exception of the 1955 summer (Fig. S1). To minimize this year-to-year variability on the long-term trend we smoothed the summer ice record (first component of single spectra analysis with a 7-yr time window, Fig. 2). Because of the lack of winters values we here applied a robust spline smoothing (Bloomfield and Steiger, 1983).

The rather high bromine summer level detected in 1995 (Fig. 2) cannot be attributed to enhanced vertical transport at that time (Fig S1). Considering ice core dating uncertainty, we suspect that part of these 1955 summer layers were impacted by the Bezymianny 1956 eruption (see Text S2). Removal of this bromine perturbation ( $8 \mathrm{cmwe}$, Text S2) leads to a 1955 half-year summer bromine mean of $1.0 \mathrm{ng} \mathrm{g}^{-1}$ instead of $1.76 \mathrm{ng} \mathrm{g}^{-1}$ when all samples are considered.

In Fig. 2, bromine concentrations observed in layers with a density lower than $0.83 \mathrm{~g} \mathrm{~cm}^{-3}$ (i.e., the density at the firn-ice transition) are shown as grey circles. Legrand et al. (2018) reported that iodine concentrations in these layers were low compared to those in adjacent ice 
suggesting that a significant fraction of iodine escaped from the firn samples by volatilization during storage or analysis. Such an effect is not seen for bromine (Fig. 2), consistent with the less volatile character of bromine compared to iodine species (Text S1). We also found no systematic deviation in bromine levels in recent ice layers characterized by high $(>1.5$ mwe $)$ and low $(<0.5$ mwe) annual ice layer thickness suggesting that remobilization of bromine after deposition does not affect significantly the CDD ice-core bromine record (Text S1).

\section{Bromine Aerosol}

Bromine aerosol and inorganic bromine gases, that are both incorporated in precipitation and ice, have very different atmospheric reactivity. Except sea-salt from which a large fraction of bromine is released within the gas phase after emission, bromine aerosol is rather unreactive whereas some species of the $\mathrm{Br}_{\mathrm{y}}$ family are very reactive. To separate the two contributions (aerosol and inorganic gases) with respect to observed changes of total bromine in alpine ice, we used ancillary data including sodium, cerium and lead.

\subsection{Natural Bromine Aerosol}

The main natural sources of primary aerosol containing bromine are sea-salt and soil dust. Legrand et al. (2002) reported averaged sodium levels in CDD ice of $15 \mathrm{ng} \mathrm{g}^{-1}$ in summer and $5 \mathrm{ng} \mathrm{g}^{-1}$ in winter. Whereas in winter, most of the sodium in CDD ice is thought to be related to sea-salt, in summer less than $7 \mathrm{ng} \mathrm{g}^{-1}$ of sodium on a total of $15 \mathrm{ng} \mathrm{g}^{-1}$ is attributed to sea-salt (Legrand et al., 2002). Using these sodium values and considering the $\mathrm{Br} / \mathrm{Na}$ mass ratio of 6.25 $10^{-3}$ in seawater (Pilson, 1998), we estimated a sea-salt bromine contribution of $\sim 0.04 \mathrm{ng} \mathrm{g}^{-1}$ (compared to an overall average of 1.05 and $0.45 \mathrm{ng} \mathrm{g}^{-1}$ of bromine in summer and winter, respectively). This value is clearly an upper limit because of the pervasive release of bromine from sea-salt (Sander et al., 2003), leading to the conclusion that the fraction of bromine directly related to sea-salt aerosol is insignificant at the CDD site. It is important to emphasize, however, that such a low contribution of sea-salt aerosol to the level of bromine present in CDD ice does not mean that the release of bromine from sea-salt aerosol emitted within the marine boundary layer of oceanic regions located offshore western Europe did not contribute to the $\mathrm{Br}_{\mathrm{y}}$ budget in the free troposphere over the western part of the European continent.

The crustal contribution of bromine can be estimated using cerium concentrations and considering a $\mathrm{Br} / \mathrm{Ce}$ mass ratio of 0.23 in mean sediments (Bowen, 1966). From that and given the averaged cerium levels $\left(0.055 \mathrm{ng} \mathrm{g}^{-1}\right.$ in summer, and $0.008 \mathrm{ng} \mathrm{g}^{-1}$ in winter layers $)$, the soil contribution to bromine levels of CDD ice remains on the order of $1 \%$. In addition to bromine aerosol emitted as soil dust, Saharan dust plumes sporadically reach the Alps and can strongly disturb the level of numerous chemical species in alpine ice because these species either were present in dust at the emission stage or, being acidic, were taken up during transport by alkaline material (Usher et al., 2003). In the case of bromine, as detailed in the SI (Text S3), the bromine content of saharan dust at the emission stage would be similar to that in dust. For CDD ice samples identified as containg Saharan dust (see Text S3), Fig. 3 indicates a slope of the linear relationship between $\mathrm{Br}$ and Ce correlation of $2.95 \pm 0.26$, being far larger than the $\mathrm{Br} / \mathrm{Ce}$ mass ratio in mean sediments (0.23; Bowen (1966)). It is thus likely that bromine enrichment from 10 relative to mean sediments seen in CDD ice samples contaminated by Saharan dust is not a result of the presence of bromine in Saharan dust at the emission stage. Instead, given the acidic character of several Bry species (HOBr, $\mathrm{HBr}$ ), and as seen for various acidic species (Usher et al., 
2003), it is likely that the increase of bromine seen in CDD samples containing Saharan dust also results from uptake of bromine by alkaline material during transport. Since the occurrence of Saharan dust plumes reaching the Alps has changed over the past (Arienzo et al. (2021) and references therehein), the increasing trend seen in total bromine concentration (black line in Fig. 2) that reached a maximum around 1975 may have been influenced by more frequent Saharan dust events particularly during the 1970-1980 decade (also at the end of the 1950s and at the end of the last century). To correct the bromine trend for this effect, as detailed in Text S3, we corrected total bromine concentrations using two approaches (Brred1 denoted as red line and Brred2 as blue line in Fig. 2), the preferred correction being Brred2 (blue line in Fig. 2).

\subsection{Anthropogenic Aerosol from Leaded-gasoline Combustion}

In addition to coal burning that emits $\mathrm{HBr}$ into the atmosphere (section 5), the main fossil-fuel related source of bromine is leaded-gasoline combustion. Large quantities of 1,2dibromoethane were added to leaded-fuel as a scavenger for $\mathrm{Pb}$, thereby preventing lead-oxide deposition by converting it to volatile lead-bromide salts (Nriagu, 1990; Oudijk, 2010). During leaded-gasoline combustion, it has been shown that most bromine is emitted as $\mathrm{PbBrCl}$ particles (Habibi, 1973), as an upper limit 15 to $28 \%$ as methyl bromide $\left(\mathrm{CH}_{3} \mathrm{Br}\right)$ (Baumann \& Heumann, 1987), and only $1 \%$ as $\mathrm{HBr}$. The freshly emitted bromine aerosol has a $\mathrm{Br} / \mathrm{Pb}$ mass ratio of 0.386. Several studies suggest that lead dihalide is not stable in the atmosphere (Robbins \& Snitz, 1972; Terhaar \& Bayard, 1971) because of a possible release of $\mathrm{HBr}$ in the presence of acidic species (Harrison \& Sturges, 1983). Atmospheric measurements tend to show a decrease in the $\mathrm{Br} / \mathrm{Pb}$ ratio from urban ( 0.35) to suburban ( 0.25) sites, suggesting a slow, but significant, release of bromine from $\mathrm{PbBrCl}$ aerosol after emission. As a result, the use of $\mathrm{ncPb}$ to accurately evaluate the contribution of leaded-gasoline combustion to the bromine CDD ice content (hereafter denoted $\mathrm{PbBrCl}^{*}$ ) is not simple. In addition, since leaded-gasoline combustion is not the only source of atmospheric $\mathrm{ncPb}$, the fraction of $\mathrm{ncPb}$ related to the use of leadedgasoline and its change during the past have to be considered when using $\mathrm{ncPb}$ ice concentration as a surrogate of $\mathrm{PbBrCl}^{*}$.

As detailed in the SI (Text S4), ncPb deposition fluxes at the CDD site were calculated by using estimated $\mathrm{Pb}$ emissions from the different European countries for each source category (leaded-gasoline combustion, coal burning, non-ferrous smelters, and the iron and steel industry) and the sensitivity of the CDD site to emissions calculated by state-of-the-art FLEXPART atmospheric aerosol deposition and transport modelling (Legrand et al., 2020). It was shown that from 1960 to 2000, the $\mathrm{ncPb}$ ice record at CDD is in good agreement with estimated $\mathrm{Pb}$ emissions (Pacyna \& Pacyna, 1999; Pacyna et al., 2009). These were dominated by leadedgasoline emissions since the mid- $20^{\text {th }}$ century (up to $76 \%$ in 1975 ; Fig. S4, SI). Such agreement between the ice core record, estimated past emissions, and deposition demonstrate good knowledge of $\mathrm{Pb}$ pollution in Europe during the second part of the $20^{\text {th }}$ century. Therefore, we used the fraction of leaded-gasoline combustion contributing to the $\mathrm{ncPb}$ deposition in the CDD ice, as calculated by the FLEXPART model using estimated $\mathrm{Pb}$ emissions during that period (Pacyna \& Pacyna, 1999; Pacyna et al., 2009) (red points in Fig. 4).

Prior to 1955 , no $\mathrm{Pb}$ inventories exist for Europe but, based on statistics of relevant source categories, Legrand et al. (2020) estimated past anthropogenic Pb emissions in European countries and the corresponding deposition fluxes at CDD back to 1890. Results show that 
estimated $\mathrm{Pb}$ deposition at $\mathrm{CDD}$ was underestimated with respect to ice concentrations, with underestimation ranging from a factor of 1.6 in 1955, to 1.85 in 1950, and to more than a factor of 2.0 prior to 1950 (Fig. S4, SI). Legrand et al. (2020) attributed this difference to underestimation of emission factors used to calculate the dominant source categories (i.e., nonferrous smelters, the iron and steel industry, and coal burning) that together dominate (70\%) the leaded-gasoline contribution (30\%) between 1940 and 1950 for instance (Fig. S4, SI). From that, the leaded-gasoline contribution to total $\mathrm{Pb}$ anthropogenic emissions calculated from statistics was corrected (blue points in Fig. 4) by using a factor $(\alpha)$ (black line in Fig. 4) that fits calculated $\mathrm{Pb}$ deposition at CDD to observed ice core concentrations. By dividing the calculated leadedgasoline contribution by $\alpha$ to derive the corrected leaded-gasoline contributions, we assumed that underestimation of $\mathrm{Pb}$ deposition with respect to $\mathrm{ncPb}$ ice core concentrations was from underestimation of emissions from non-ferrous smelters, the iron and steel industry, and coal burning but not those of leaded-gasoline. Between 1950 and 1960, no change with respect to 1955 is expected either in the amount of additive in gasoline or in the composition of additive (Oudijk, 2010), and the corrected values of the leaded-gasoline contribution to total $\mathrm{Pb}$ deposition in ice (blue dots in Fig. 4) are thus reasonable estimates of leaded gasoline contribution to $\mathrm{Pb}$ deposition at that time. For the period prior to 1950 , the above correction becomes less accurate since calculations did not consider changes of the additive content (or composition) of leaded gasoline. These changes are poorly documented for Europe but based on Oudijk (2010), a decrease by almost a factor of 2 from 1950 to 1945 of the $\mathrm{Pb}$ content in gasoline should be considered. Also, at the 1940 onset of the use of additive for car gasoline in Europe we also have to consider a change in the additive composition with a shift from dibromo-ethane (i.e., a $\mathrm{Br} / \mathrm{Pb}$ of 0.8 ) to a mixture of dibromo- and dichloro-ethane $(\mathrm{Br} / \mathrm{Pb}$ of 0.38$)$. Therefore, the calculated leaded-gasoline contribution used to calculate $\mathrm{PbBrCl}^{*}$ (marked with a blue dashed rectangle in Figs. 6 and 7) has to be considered with caution during the 1940-1950 decade.

We first calculated past $\mathrm{PbBrCl}^{*}$ ice levels as an upper limit, by applying a $\mathrm{Br} / \mathrm{Pb}$ mass ratio of 0.386 to the fraction of $\mathrm{ncPb}$ observed in ice being related to leaded-gasoline combustion (Fig. 4). In addition, to account for possible release of bromine after $\mathrm{PbBrCl}$ aerosol emission, we examined the linear relationship between bromine and lead observed in CDD ice layers deposited across time periods when the leaded-gasoline aerosol emissions likely dominated the correlation. We (1) did not consider samples suspected to contain significant Saharan dust and (2) focused on summer samples in which we expect a larger contribution of $\mathrm{PbBrCl}$ emitted within the polluted boundary layer than in winter. We chose the 1955-1975 years (Fig. 5), a time period during which the $\mathrm{ncPb}$ concentration in CDD ice was greatly enhanced (from $1.6 \mathrm{ng} \mathrm{g}^{-1}$ to $2.5 \mathrm{ng} \mathrm{g}^{-1}$; Fig. 6), mainly as a result of a growing contribution of leaded-gasoline combustion to lead deposition at CDD. We also examined the $\mathrm{Br}-\mathrm{Pb}$ relationship in CDD ice deposited between 1965 and 1980 (Fig. 5) when ncPb concentrations in CDD ice remained close to their maximum (more than $2 \mathrm{ng} \mathrm{g}^{-1}$; Fig. 6); and the contribution of the leaded-gasoline to the total $\mathrm{ncPb}$ deposition in CDD ice remained at its maximum value ( $70-75 \%$; Fig. 4), other contributions related to non-ferrous smelters, iron-steel industry, and coal burning remained stable. In this way, the derived slope of the observed $\mathrm{Br}-\mathrm{Pb}$ linear relationships would reflect the $\mathrm{Br} / \mathrm{Pb}$ ratio of bromine aerosol emitted by leaded-gasoline combustion reaching the CDD site. The two observed values ( 0.25 and 0.30 ; Fig. 5) indicated a slight departure from the $\mathrm{Br} / \mathrm{Pb}$ ratio at the emission stage. If reflecting a loss of bromine from $\mathrm{PbBrCl}$ aerosol during transport to the $\mathrm{CDD}$ site, these values can be used (instead of 0.386 ) to calculate $\mathrm{PbBrCl}^{*}$ levels by using $\mathrm{ncPb}$ ice core concentrations. Since the observed departure in the $\mathrm{Br} / \mathrm{Pb}$ ratio from 0.386 to $0.25-0.30$ may 
also be partly a result of the fact that, even over the considered time periods (1955-1980), a fraction of $\mathrm{ncPb}$ is still not related to the leaded-gasoline source, the use of the mean $\mathrm{Br} / \mathrm{Pb}$ ratio of 0.27 to calculate the $\mathrm{PbBrCl}^{*}$ levels would represent a lower estimate.

In Table 1, we report the $\mathrm{PbBrCl}^{*}$ levels (maximum, minimum, and mean) calculated using a $\mathrm{Br} / \mathrm{Pb}$ ratio of 0.386 (maximum) and 0.27 (minimum). As previously discussed, prior to 1950 , the contribution of leaded-gasoline to past $\mathrm{Pb}$ deposition at CDD is less accurately known than from 1960 to 2000, the induced absolute errors in calculating the $\mathrm{PbBrCl}^{*}$ levels remained small, however, because of (1) a leaded-gasoline contribution to the ncPb deposited at CDD remaining well below $50 \%$ (Fig. 4) and (2) a low ncPb content in ice deposited at that time ( 1 $\mathrm{ng} \mathrm{g}^{-1}$; Table 1). Also, even if the value of the $\mathrm{Br} / \mathrm{Pb}$ ratio of anthropogenic bromine aerosol reaching the $\mathrm{CDD}$ site is uncertain, the low $\mathrm{ncPb}$ concentration in ice during the last decade of the $20^{\text {th }}$ century $\left(\sim 0.7 \mathrm{ng} \mathrm{g}^{-1}\right.$; Table 1$)$ renders the estimate of $\mathrm{PbBrCl}^{*}$ levels rather accurate, and definitively suggests the existence of another anthropogenic source of bromine not related to $\mathrm{PbBrCl}$ aerosol in CDD ice (Table 1). In summer, on a total-bromine increase of $0.7 \mathrm{ng} \mathrm{g}^{-1}$ from 1930-1950 to 1965-1980, 0.5 $\mathrm{ng} \mathrm{g}^{-1}$ (i.e., 70\%) are from the increase in leaded-gasoline combustion. In winter, the increase of leaded-gasoline combustion had a weaker impact on the increase in total bromine ( $30 \%$ of the Br increase from 1930-1950 to 1965-1980). Such a weaker contribution of leaded-gasoline combustion in winter than in summer is expected because of less efficient upward transport of species emitted within the polluted boundary to the site during that season.

\section{The past $\mathrm{Br}_{\mathrm{y}}{ }^{*}$ budget}

The calculated $\mathrm{PbBrCl}^{*}$ levels were subtracted from the total bromine CDD ice concentrations. The resulting ice concentrations are related to inorganic bromine atmospheric gases $\left(\mathrm{Br}_{\mathrm{y}}\right)$, and were denoted Bry* (Table 1). The summer and winter records of Bry* in CDD ice are shown in Figs. 6 and 7, respectively.

Coal burning is a possible anthropogenic source of bromine in the atmosphere (mainly as HBr; Germani \& Zoller (1988); Xu et al. (2004)), and therefore may contribute to Bry* levels in CDD ice. The bromine content of coal is highly variable (see Swaine (1990) for a review). Raask (1985) reported $45 \mathrm{ppm}$ of bromine and $23 \mathrm{ppm}$ of $\mathrm{Pb}$ in 21 samples of British coal. The corresponding $\mathrm{Br} / \mathrm{Pb}$ ratio ( 2) has to be considered with caution since UK coal is more enriched in bromine relative to lead than coals from other European countries (Swaine, 1990).

Furthermore, the use of lead to estimate the bromine contribution of coal combustion in the ice is not straightforward since the $\mathrm{Br} / \mathrm{Pb}$ ratio at the emission stage is likely not conservative and would rapidly decrease during transport to the site because $\mathrm{HBr}$ (a highly water soluble gas) would have a shorter atmospheric lifetime than sub-micron noncrustal $\mathrm{Pb}$ aerosol. Estimating the $\mathrm{Br} / \mathrm{Pb}$ ratio corresponding to coal burning by examining the $\mathrm{Br}-\mathrm{Pb}$ relationship in $\mathrm{CDD}$ ice is far more difficult than for leaded gasoline, since even in the 1920 to 1945 period the contribution of coal to Pb deposition at the CDD site (Fig S4, SI) was low (less than 20\%) compared to contributions related to iron and non-ferrous metal production.

The Bry* levels observed prior to 1945 ranged from $~ 0.6$ to $0.8 \mathrm{ng} \mathrm{g}^{-1}$ in summer (Fig. 6) and $\sim 0.31$ to $0.36 \mathrm{ng} \mathrm{g}^{-1}$ in winter (Fig. 7). These pre-1945 values were not significantly different from the Br concentrations (corrected from Saharan dust) observed in ice layers deposited during pre-industrial times (0.7 to $0.8 \mathrm{ng} \mathrm{g}^{-1}$ in summer, $\sim 0.35 \mathrm{ng} \mathrm{g}^{-1}$; Table 2$)$. Such an absence of significant increase in Br levels from pre-industrial times to 1920-1945, when anthropogenic 
emissions from consumption of coal in Europe reached a maximum, indicates that, if it exists, the bromine contribution from coal burning at the CDD site was a minor during the $20^{\text {th }}$ century. Assuming as an upper limit a $\mathrm{Br} / \mathrm{Pb}$ ratio of 2 for coal burning emissions and that $20 \%$ of $\mathrm{Pb}$ deposited at CDD is related to coal burning prior to 1945 , the mean summer Pb level of $\sim 0.9 \mathrm{ng}$ $\mathrm{g}^{-1}$ at that time in CDD ice (Figure 6) leads to a coal-related bromine contribution of $0.36 \mathrm{ng} \mathrm{g}^{-1}$. Such a contribution, not observed in the ice record, is very likely overestimated because of (1) the expected decrease of the $\mathrm{Br} / \mathrm{Pb}$ ratio during transport and (2) the assumption of a $\mathrm{Br} / \mathrm{Pb}$ ratio of 2 for coal burning emissions.

Assuming a pre-industrial value of Bry* of $0.7 \mathrm{ng} \mathrm{g}^{-1}$ in summer (Table 2), Table 1 indicates an increase of Bry* summer levels by a factor of $20 \%$ in $1965-1980$ and $40 \%$ in 1990 2000. A similar Bry* increase was observed in winter (a factor of $28 \%$ in 1965-1980, $40 \%$ in 1990-2000). The past changes of Bry* therefore differed from those of $\mathrm{PbBrCl}^{*}$ that were higher in summer than in winter. Such a summer-winter difference in the trends of the two bromine components, also seen in Fig. 1, may be caused by their different source locations, with Bry in the free troposphere and $\mathrm{PbBrCl}$ within the continental boundary layer.

Past changes of Bry* derived from the CDD bromine records can be compared to model simulations that evaluate recent changes in bromine chemistry. For example, using the GEOSChem model, Sherwen et al. (2017) reported a global increase of Bry of 39\% from pre-industrial to 2005. These simulations included natural emissions of $\mathrm{CHBr}_{3}, \mathrm{CH}_{2} \mathrm{Br}$, and $\mathrm{CH}_{3} \mathrm{Br}$, but not address sea-salt debromination. Anthropogenic emissions included $\mathrm{CH}_{3} \mathrm{Br}$ from fumigation in the agricultural industry and leaded-gasoline combustion (Reeves, 2003), as well as the degradation of $\mathrm{CFCs}$ and halons $\left(\mathrm{CF}_{3} \mathrm{Br}\right.$ and $\left.\mathrm{CF}_{2} \mathrm{ClBr}\right)$ within the stratosphere. The model also accounted for changes of bromine induced by increasing iodine-driven sea-salt cycling of bromine, with the increase of iodine resulting from ozone increase over the ocean. The simulated bromine increase is approximately homogeneous from the boundary layer to the mid-troposphere (40 to $30 \%$ ), only increasing significantly at $15 \mathrm{~km}$ altitude. We can thus conclude that our estimated increase of Bry* in alpine ice is consistent with current model simulations of bromine chemistry.

Although it is difficult to understand the cause of the observed changes of Bry* in alpine ice during the second part of the $20^{\text {th }}$ century with respect to temporal changes in atmospheric anthropogenic precursors of Bry, we emphasize that the summer trend in Bry* indicates that the most important increase occurred between the 1960 to 1970 period and 1978 (Fig. 6), suggesting a dominant role of $\mathrm{CH}_{3} \mathrm{Br}$ rather than halons in the atmospheric budget of Bry at that time. This conclusion is consistent with understanding of past anthropogenic bromine emissions. Indeed, the history of $\mathrm{CF}_{3} \mathrm{Br}$ and $\mathrm{CF}_{2} \mathrm{ClBr}$ archived in firn and ice (Vollmer et al., 2016) indicates an increase between 1980 and 2000 from 0.7 to 4.3 pptv and 0.37 to 2.9 pptv between 1980 and 2000, respectively. These halon increases resulted from their use as fire suppressants in fire extinguishers. In contrast, although uncertainties exist in the present-day and pre-industrial budget of $\mathrm{CH}_{3} \mathrm{Br}$ (Reeves, 2003), the anthropogenic sources of $\mathrm{CH}_{3} \mathrm{Br}$ already were large in 1980 (reaching half of those in 1990-2000), mainly from agricultural usage (fumigation). Fig. 6 also indicates that the Bry* increase already was significant in the mid 1970s suggesting that leadedgasoline emissions of $\mathrm{CH}_{3} \mathrm{Br}$ were significant.

Although less clear than the summer trend in CDD, the winter trend showed an increase in Bry* starting in $\sim 1950$ (Fig. 7). If confirmed, this winter increase during the 1950s may reflect a contribution of sea-salt debromination and its increase as a result of acidification of the 
atmosphere because of growing emissions of sulfur and nitrogen oxides. Further work including development of additional ice core records is clearly needed to better understand possible differences between winter and summer trends in bromine.

\section{Conclusions}

This work is the first investigation of changes in total bromine in alpine ice cores that, unlike polar ice cores, are not dominated by sea-ice related processes through Bry emission from sea-salt. We have shown that these alpine ice cores recorded an increase in bromine aerosol emitted by leaded-gasoline combustion which dominated other fossil fuel emissions such as $\mathrm{HBr}$ emissions from coal burning in the free troposphere over western Europe. In addition, we quantified another anthropogenic source likely related to inorganic bromine gases that increased by $\sim 40 \%$ from pre-industrial times to 2000 , in reasonably good agreement with current model simulations. Together with those recently obtained on iodine by Legrand et al. (2020), these bromine data open the possibility of using halogen ice core records extracted from mid-latitudes to constrain model simulations of present and past tropospheric ozone changes.

\section{Acknowledgments, Samples, and Data}

The ice core drilling operations at CDD were supported by the European Community via ENV4-CT97 (ALPCLIM) contract, the EU CARBOSOL project (contract EVK2 CT200100113, EVK2-2001-00067), and the Region Rhône-Alpes. The LEFE-CHAT (CNRS) program entitled "Evolution séculaire de la charge et composition de l'aérosol organique au dessus de l'Europe (ESCCARGO)" provided funding for analysis in France with the support of ADEME (Agence de l'Environnement et de la Maîtrise de l'Energie). NSF grant 1925417 to JRM provided partial support for the analyses and interpretation at DRI. We thank colleagues who participated in the drilling campaigns at CDD. R. Kreidberg at DRI provided editorial advice. The authors would also like to thank the reviewers whose comments greatly improved the manuscript. Ice core data are available at NCEI (National Centers for Environmental Information) data base https://www.ncdc.noaa.gov/paleo/study/31833.

\section{References}

Abbatt, J. (2013), Arctic snowpack bromine release, Nature Geoscience, 6, 331-332.

Abrahamsson, K., Granfors, A., Ahnoff, M., Cuevas, C. A., \& Saiz-Lopez, A. (2018), Organic bromine compounds produced in sea ice in Antarctic winter, Nature Communications, 1 , doi:10.1038/s41467-018-07062-8.

Adepetu, J., Asubiojo, O., Iskander, F., \& Bauer, T. (1988), Elemental composition of Nigerian Harmattan dust, Journal of Radioanalytical and Nuclear Chemistry-Articles, 121(1), 141-147, doi:10.1007/BF02041455.

Arienzo, M. M., Legrand, M., Preunkert, S., Stohl, A., Chellman, N., Eckhardt, S., et al. (2021). Alpine ice-core evidence Europe during the 20th century, Journal of Geophysical Research: Atmospheres, 126, e2020JD033211. https://doi. org/10.1029/2020JD033211. 
Baumann, H., \& Heumann, K. (1987), Analysis of organobromine compounds and HBr in motor car exhaust-gases with a GC microwave plasma system, Fresenius Zeitschrift Fur Analytische Chemie, 327(2), 186-192, doi:10.1007/BF00469815.

Bloomfield, P. \& Steiger, W. L. (1983), Last absolute deviations: Theory, Aplications and Algorithms, Bitkhauser, Boston, Mass.

Bottenheim, J. W., Gallant, A. G., \& Brice, K. A. (1986), Measurements of $\mathrm{NO}_{y}$ species and $\mathrm{O}_{3}$ at $82^{\circ} \mathrm{N}$ latitude, Geophysical Research Letters, 13(2), 113-116, doi:10.1029/GL013i002p00113.

Bowen, H. (1966), Trace Elements in Biochemistry, Academic Press, New York.

Fagerli, H., Legrand, M., Preunkert, S., Vestreng, V., Simpson, D., \& Cerqueira, M. (2007), Modeling historical long-term trends of sulfate, ammonium, and elemental carbon over Europe: A comparison with ice core records in the Alps, Journal of Geophysical Research, 112, D23S13, doi:10.1029/2006JD008044.

Friess, U., Hollwedel, J., Konig-Langlo, G., Wagner, T., \& Platt, U. (2004), Dynamics and chemistry of tropospheric bromine explosion events in the Antarctic coastal region, Journal of Geophysical Research-Atmospheres, 109(D6), doi:10.1029/2003jd004133.

Gerlach, T. (2004), Volcanic sources of tropospheric ozone-depleting trace gases, Geochemistry Geophysics Geosystems, 5, doi:10.1029/2004GC000747.

Germani, M., \& Zoller, W. (1988), Vapor-phase concentrations of arsenic, selenium, bromine, iodine, and mercury in the stack of a coal-fired power-plant, Environmental Science \& Technology, 22(9), 1079-1085, doi:10.1021/es00174a013.

Habibi, K. (1973), Characterization of particulate matter in vehicle exhaust, Environmental Science \& Technology, 7(3), 223-234, doi:10.1021/es60075a001.

Halmer, M. M., Schmincke, H.U., \& Graf, H. F. (2002), The annual volcanic gas input into the atmosphere, in particular into the stratosphere: a global data set for the past 100 years, Journal of Volcanology and Geothermal Research, 115(3-4), 511-528, doi:10.1016/s0377-0273(01)00318-3.

Harrison, R., \& Sturges, W. (1983), The measurement and interpretation of $\mathrm{Br} / \mathrm{Pb}$ ratios in airborne particles, Atmospheric Environment, 17(2), 311-328, doi:10.1016/0004-6981(83)90048-3.

Jacobi, H. W., Voisin, D., Jaffrezo, J. L., Cozic, J., \& Douglas, T. A. (2012), Chemical composition of the snowpack during the OASIS spring campaign 2009 at Barrow, Alaska, Journal of Geophysical Research, 117, D00R13, doi:10.1029/2011JD016654.

Kurylo, M., \& Rodriguez J. (1999), Short-lived ozone-related compoundsRep., 2.1 - 2.56 pp, World Meteorological Ogranization, Geneva.

Legrand, M., McConnell, J., Preunkert, S., Arienzo, M., Chellman, N., Gleason, K., Sherwen, T., Evans, M., \& Carpenter, L. (2018), Alpine ice evidence of a three-fold increase in atmospheric iodine deposition since 1950 in Europe due to increasing oceanic emissions, Proceedings of the National Academy of Sciences of the United States of America, 115(48), 12136-12141, doi:10.1073/pnas.1809867115.

Legrand, M., McConnell, J. R., Lestel, L., Preunkert, S., Arienzo, M., Stohl, A., Eckhardt, S., \& Chellman, N. J. (2020), Alpine ice evidence of maximal pollution by cadmium from zinc smelters and lead from leaded gasoline in the 1970s in Europe, Geophysical Research Letters, 
Legrand, M., Preunkert, S., Jourdain, B., Guilhermet, J., Fain, X., Alekhina, I., \& Petit, J.-R. (2013), Water-soluble organic carbon in snow and ice deposited at Alpine, Greenland, and Antarctic sites: a critical review of available data and their atmospheric relevance, Climate of the Past, 9(5), 2195-2211, doi:10.5194/cp-9-2195-2013.

Legrand, M., Preunkert, S., Wagenbach, D., \&Fischer, H. (2002), Seasonally resolved Alpine and Greenland ice core records of anthropogenic $\mathrm{HCl}$ emissions over the 20th century, Journal of Geophysical Research-Atmospheres, 107(D12), doi:10.1029/2001JD001165.

Legrand, M., Yang, X., Preunkert, S., \& Theys, N. (2016), Year-round records of sea salt, gaseous, and particulate inorganic bromine in the atmospheric boundary layer at coastal (Dumont d'Urville) and central (Concordia) East Antarctic sites, Journal of Geophysical Research-Atmospheres, 121(2), 997-1023, doi:10.1002/2015JD024066.

Liang, Q., Atlas, E., Blake, D., Dorf, M., Pfeilsticker, K., \& Schauffler, S. (2014), Convective transport of very short lived bromocarbons to the stratosphere, Atmospheric Chemistry and Physics, 14(11), 5781-5792, doi:10.5194/acp-14-5781-2014.

Maselli, O. J., Chellman, N. J., Grieman, M., Layman, L., McConnell, J. R., Pasteris, D., Rhodes, R. H., Saltzman, E., \& Sigl, M. (2017), Sea ice and pollution-modulated changes in Greenland ice core methanesulfonate and bromine, Climate of the Past, 13(1), 39-59, doi:10.5194/cp-13-392017.

McConnell, J., et al. (2017), Synchronous volcanic eruptions and abrupt climate change $\sim 17.7 \mathrm{ka}$ plausibly linked by stratospheric ozone depletion, Proceedings of the National Academy of Sciences of the United States of America, 114(38), 10035-10040, doi:10.1073/pnas.1705595114.

McConnell, J., et al. (2019), Pervasive Arctic lead pollution suggests substantial growth in medieval silver production modulated by plague, climate, and conflict, Proceedings of the National Academy of Sciences of the United States of America, 116(30), 14910-14915, doi:10.1073/pnas.1904515116.

McConnell, J. R., Wilson, A., Stohl, A., Arienzo, M., Chellman, N., Eckhardt, S., Thompson, E., Pollard, A., \& Steffensen, J.P. (2018), Lead pollution recorded in Greenland ice indicates European emissions tracked plagues, wars, and imperial expansion during antiquity, Proceedings of the National Academy of Sciences of the United States of America, 115(22), 5726-5731, doi:10.1073/pnas.1721818115.

Nriagu, J. (1990), The rise and fall of leaded gasoline, Science of the Total Environment, 92, 1328, doi:10.1016/0048-9697(90)90318-O.

Oppenheimer, C., Pyle, D., \& Barclay, J. (Eds.) (2003), Volcanic Degassing, The Geological Society, London.

Oppenheimer, C., Tsanev, V., Braban, C., Cox, R., Adams, J., Aiuppa, A., Bobrowski, N., Delmelle, P., Barclay, J., \& McGonigle, A. (2006), BrO formation in volcanic plumes, Geochimica Et Cosmochimica Acta, 70(12), 2935-2941, doi:10.1016/j.gca.2006.04.001.

Ordonez, C., Lamarque, J., Tilmes, S., Kinnison, D., Atlas, E., Blake, D., Santos, G., Brasseur, G., \& Saiz-Lopez, A. (2012), Bromine and iodine chemistry in a global chemistry-climate model: 
description and evaluation of very short-lived oceanic sources, Atmospheric Chemistry and Physics, 12(3), 1423-1447, doi:10.5194/acp-12-1423-2012.

Oudijk, G. (2010), The Rise and Fall of Organometallic Additives in Automotive Gasoline, Environmental Forensics, 11(1-2), 17-49, doi:10.1080/15275920903346794.

Pacyna, J., \& Pacyna, E. (1999), Atmospheric emissions of anthropogenic lead in Europe: Improvements, updates, historical data and projectionsRep., $36 \mathrm{pp}$, GKSS Research Center, Geesthacht.

Pacyna, J., Pacyna, E., \& Aas, W. (2009), Changes of emissions and atmospheric deposition of mercury, lead, and cadmium, Atmospheric Environment, 43(1), 117-127, doi:10.1016/j.atmosenv.2008.09.066.

Parrella, J., et al. (2012), Tropospheric bromine chemistry: implications for present and preindustrial ozone and mercury, Atmospheric Chemistry and Physics, 12(15), 6723-6740, doi:10.5194/acp-12-6723-2012.

Pilson, M. E. Q. (1998). An Introduction to the Chemistry of the Sea, 2nd ed., Cambridge University Press, New York.

Preunkert, S., \& Legrand, M. (2013), Towards a quasi-complete reconstruction of past atmospheric aerosol load and composition (organic and inorganic) over Europe since 1920 inferred from Alpine ice cores, Climate of the Past, 9(4), 1403-1416, doi:10.5194/cp-9-1403-2013.

Preunkert, S., Legrand, M., \& Wagenbach, D. (2001), Sulfate trends in a Col du Dome (French Alps) ice core: A record of anthropogenic sulfate levels in the European midtroposphere over the twentieth century, Journal of Geophysical Research-Atmospheres, 106(D23), 31991-32004, doi:10.1029/2001jd000792.

Preunkert, S., Wagenbach, D., \& Legrand, M. (2003), Seasonally resolved Alpine ice core Record of Nitrate: Comparison with Anthropogenic Inventories and estimation of Pre-Industrial Emissions of NO from Europe, Journal of Geophysical Research, 108, D21, 4681, doi : 10.1029/2003JD003475, 2003.

Preunkert, S., McConnell, J., Hoffmann, H., Legrand, M., Wilson, A., Eckhardt, S., Stohl, A., Chellman, N., Arienzo, M., \& Friedrich, R. (2019), Lead and Antimony in Basal Ice From Col du Dome (French Alps) Dated With Radiocarbon: A Record of Pollution During Antiquity, Geophysical Research Letters, 46(9), 4953-4961, doi:10.1029/2019GL082641.

Preunkert, S., Wagenbach, D., Legrand, M., \& Vincent, C. (2000), Col du Dome (Mt Blanc Massif, French Alps) suitability for ice-core studies in relation with past atmospheric chemistry over Europe, Tellus Series B-Chemical and Physical Meteorology, 52(3), 993-1012, doi:10.1034/j.1600-0889.2000.d01-8.x.

Pyle, D. M., \& Mather, T. A. (2009), Halogens in igneous processes and their fluxes to the atmosphere and oceans from volcanic activity: A review, Chemical Geology, 263(1-4), 110-121, doi:10.1016/j.chemgeo.2008.11.013.

Raask, E. (1985), The mode of occurrence and concentration of trace-elements in coal, Progress in Energy and Combustion Science, 11(2), 97-118, doi:10.1016/0360-1285(85)90001-2. 
Reeves, C. (2003), Atmospheric budget implications of the temporal and spatial trends in methyl bromide concentration, Journal of Geophysical Research-Atmospheres, 108(D11), doi:10.1029/2002JD002943.

Robbins, J., \& Snitz, F. (1972), Bromine and chlorine loss from lead halide automobile exhaust particulates, Environmental Science \& Technology, 6(2), 164-169, doi:10.1021/es60061a001.

Saiz-Lopez, A., et al. (2012), Estimating the climate significance of halogen-driven ozone loss in the tropical marine troposphere, Atmospheric Chemistry and Physics, 12(9), 3939-3949, doi:10.5194/acp-12-3939-2012.

Saiz-Lopez, A., Mahajan, A. S., Salmon, R. A., Bauguitte, S. J. B., Jones, A. E., Roscoe, H. K., \& Plane, J. M. C. (2007), Boundary layer halogens in coastal Antarctica, Science, 317(5836), 348351, doi:10.1126/science.1141408.

Sander, R., et al. (2003), Inorganic bromine in the marine boundary layer: a critical review, Atmospheric Chemistry and Physics, 3, 1301-1336, doi:10.5194/acp-3-1301-2003.

Schmidt, J., et al. (2016), Modeling the observed tropospheric BrO background: Importance of multiphase chemistry and implications for ozone, $\mathrm{OH}$, and mercury, Journal of Geophysical Research-Atmospheres, 121(19), 11819-11835, doi:10.1002/2015JD024229.

Sherwen, T., Evans, M., Carpenter, L., Schmidt, J., \& Mickley, L. (2017), Halogen chemistry reduces tropospheric O-3 radiative forcing, Atmospheric Chemistry and Physics, 17(2), 15571569, doi:10.5194/acp-17-1557-2017.

Sherwen, T., et al. (2016), Global impacts of tropospheric halogens (Cl, Br, I) on oxidants and composition in GEOS-Chem, Atmospheric Chemistry and Physics, 16(18), 12239-12271, doi:10.5194/acp-16-12239-2016.

Simpson, W., Brown, S., Saiz-Lopez, A., Thornton, J., \& von Glasow, R. (2015), Tropospheric Halogen Chemistry: Sources, Cycling, and Impacts, Chemical Reviews, 115(10), 4035-4062, doi:10.1021/cr5006638.

Spolaor, A., Opel, T., McConnell, J., Maselli, O., Spreen, G., Varin, C., Kirchgeorg, T., Fritzsche, D., Saiz-Lopez, A., \& Vallelonga, P. (2016), Halogen-based reconstruction of Russian Arctic sea ice area from the Akademii Nauk ice core (Severnaya Zemlya), Cryosphere, 10(1), 245-256, doi:10.5194/tc-10-245-2016.

Spolaor, A., et al. (2013), Halogen species record Antarctic sea ice extent over glacial-interglacial periods, Atmospheric Chemistry and Physics, 13(13), 6623-6635, doi:10.5194/acp-13-6623-2013.

Swaine, D. J. (1990), Trace elements in coal, Butherworth \& Co, London.

Terhaar, G., \& Bayard, M. (1971), Composition of airborne lead particles, Nature, 232, 553-554. Thomas, V., Bedford, J., \& Cicerone, R. (1997), Bromine emissions from leaded gasoline, Geophysical Research Letters, 24(11), 1371-1374, doi:10.1029/97GL01243.

Usher, C. R., Michel, A. E., \& Grassian, V. H. (2003), Reactions on mineral dust, Chemical Reviews, 103(12), 4883-4939, doi:10.1021/cr020657y.

Volkamer, R., et al. (2015), Aircraft measurements of BrO, IO, glyoxal, NO2, H2O, O-2-O-2 and aerosol extinction profiles in the tropics: comparison with aircraft-/ship-based in situ and lidar 
measurements, Atmospheric Measurement Techniques, 8(5), 2121-2148, doi:10.5194/amt-8-21212015.

Vollmer, M., et al. (2016), Atmospheric histories and global emissions of halons H-1211 (CBrClF2), H-1301 (CBrF3), and H-2402 (CBrF2CBrF2), Journal of Geophysical ResearchAtmospheres, 121(7), 3663-3686, doi:10.1002/2015JD024488.

von Glasow, R., von Kuhlmann, R., Lawrence, M. G., Platt, U., \& Crutzen, P. J. (2004), Impact of reactive bromine chemistry in the troposphere, Atmospheric Chemistry and Physics, 4, 24812497, doi:10.5194/acp-4-2481-2004.

Wagenbach, D., Preunkert, S., Schaefer, J., Jung, W., \& Tomadin, L. (1996), Northward transport of Saharan dust recorded in a deep Alpine ice core, in The impact of African dust across the Mediterranean, edited by S. Guerzoni and R. Chester, pp. 291-300, Kluwer Academic Publishers, The Netherlands.

Xu, M., Yan, R., Zheng, C., Qiao, Y., Han, J., \& Sheng, C. (2004), Status of trace element emission in a coal combustion process: a review, Fuel Processing Technology, 85(2-3), 215-237, doi:10.1016/S0378-3820(03)00174-7.

Yang, X., Cox, R., Warwick, N., Pyle, J., Carver, G., O'Connor, F., \& Savage, N. (2005), Tropospheric bromine chemistry and its impacts on ozone: A model study, Journal of Geophysical Research-Atmospheres, 110(D23), doi:10.1029/2005JD006244.

Yang, X., Pyle, J., \& Cox, R. (2008), Sea salt aerosol production and bromine release: Role of snow on sea ice, Geophysical Research Letters, 35, doi:10.1029/2008GL034536.

Zhu, L., et al. (2019), Effect of sea salt aerosol on tropospheric bromine chemistry, Atmospheric Chemistry and Physics, 19(9), 6497-6507, doi:10.5194/acp-19-6497-2019.

\section{Figure Captions}

Figure 1. Mean seasonal cycle of total bromine $(\mathrm{Br})$, its fraction not related to leaded gasoline (denoted $\mathrm{Br}_{\mathrm{y}}{ }^{*}$, blue vertical rectangles, see section 5), lead, and ammonium (used for seasonal dissection) in CDD ice deposited between 1930 and 1950 CE (left), 1970 and 1980 CE (middle), and 1990-2000 CE (right). The vertical bars denote year-to-year variability.

Figure 2. Summer (top) and winter (bottom) total bromine concentrations in CDD ice. Open symbols are individual summer and winter means (circles are from the C10-CDM ice cores, triangles from the CDK ice cores). Note possible volcanic perturbations for summer 1955 (denoted Bezymianny) (Text S2). Grey open circles refer to snow layers partly made of dense firn material (section 2). For summer, the lines are the first component of a single spectra analysis (SSA) with a seven-year time window for bromine (black line), when samples containing Saharan dust were removed ( $\mathrm{Br}$ red1, red line) or corrected for ( $\mathrm{Br}$ red2, blue line) 
(section Text S3). For winter, the black line refers to a robust spline smoothing. The effect of Saharan dust in winter is not significant.

Figure 3. Bromine versus cerium in summer CDD firn and ice layers suspected to contain Saharan dust (Text S3), and deposited between 1975 and 1990 (section 4.2). The Ce data have been corrected for recovery using a 1.66 scaling factor (see section 2).

Figure 4. Contributions of leaded-gasoline combustion to $\mathrm{Pb}$ deposition in CDD ice derived from Legrand et al. (2020) (red and blue symbols; Text S4, SI). For 1960-2000 during which a good agreement is observed between the ice core $\mathrm{ncPb}$ trend and estimated $\mathrm{Pb}$ emissions, we directly used data derived from Legrand et al. (2020) (red points). Prior to 1960, to account for the observed difference between ice core data and calculated depositions at CDD, we applied a factor ( $\alpha$, black line) to capture contributions of leaded-gasoline combustion to $\mathrm{Pb}$ deposition (blue points are the corrected values) (see Text S4, SI). Prior to 1950, $\alpha$ values (dashed black line) and leaded gasoline contribution (dashed blue line) are highly uncertain (see Text S4, SI).

Figure 5. Bromine versus lead concentrations in summer CDD firn and ice layers deposited between 1955 and 1975 (left) and between 1965 and 1980 (right). Samples containing Saharan dust were not considered here. Note that the relationship is virtually the same when considering the non-crustal fraction of bromine and lead since the $\mathrm{Br} / \mathrm{Ce}$ and $\mathrm{Pb} / \mathrm{Ce}$ ratios in mean sediments are identical (0.23, Bowen (1966)).

Figure 6. Top: Summer trend of total bromine (Br, black line) and its non-leaded-gasoline contribution (Bry*, red lines; section 5) in CDD deposited between 1890 and 2000, after having corrected samples from Saharan dust input (red 2, see section 4.1). The thick red line (Bry* mean) is the averaged smoothed record obtained by subtracting the leaded gasoline contribution using a $\mathrm{Br} / \mathrm{Pb}$ mass ratio of 0.386 (Bry* red2 min) and 0.27 (Bry* red2 max) (see text). The blue dashed rectangle denotes the time period during which calculations of Bry* are uncertain (See text). Bottom: Summer trend of the non-crustal fraction of lead (ncPb). The open points (black) are individual summer means, the black line the first component of a single spectra analysis (SSA) with a seven-year time window.

Figure 7. Top: Winter trend of total bromine (Br, black line) and its non-leaded-gasoline contribution (Bry*, red lines; section 5) in CDD deposited between 1920 and 2000. The smoothed curves are robust splines (RSP). The thick red line (Bry* mean) is the averaged smoothed record obtained by subtracting the leaded gasoline contribution using a $\mathrm{Br} / \mathrm{Pb}$ mass ratio of 0.386 (Bry* min) and 0.27 (Bry* max) (see text). The blue dashed rectangle denotes the time period during which calculations of Bry* are uncertain (Section 4.2). Note that, in contrast to summer, the impact of Saharan dust on winter bromine levels is insignificant. Bottom: Winter trend of the non-crustal fraction of lead $(\mathrm{ncPb})$. The open points (black) are individual summer means; the black line the robust spline smoothing. 
Tables

Table 2. Pre-1900 concentrations (mean $\pm \sigma$ ) of bromine (raw data and corrected from Saharan dust, see section 4.1) and non-crustal $\mathrm{Pb}(\mathrm{ncPb})$ in ice deposited in summer $(\mathrm{S})$ and winter $(\mathrm{W})$. Values in brackets show the median values.

\begin{tabular}{|c|c|c|c|c|}
\hline $\begin{array}{l}\text { Ice core } \\
\text { (depth in } \mathrm{m})\end{array}$ & $\begin{array}{l}\text { Age CE (Common Era) } \\
\text { (season) }\end{array}$ & $\operatorname{Br}\left(\operatorname{ng~g}^{-1}\right)$ & Brred2 (ng g $\left.{ }^{-1}\right)$ & $\mathrm{ncPb}\left(\mathrm{ng} \mathrm{g}^{-1}\right)$ \\
\hline $\begin{array}{l}\text { C10 } \\
(117.85-119.25)\end{array}$ & 1884-1894 (S) & $\begin{array}{l}0.81 \pm 0.26 \\
(0.78)\end{array}$ & $\begin{array}{l}0.76 \pm 0.18 \\
(0.78)\end{array}$ & $\begin{array}{c}0.46 \pm 0.35 \\
(0.32)\end{array}$ \\
\hline $\begin{array}{l}\text { C10 } \\
(119.9-121.5)\end{array}$ & $1863-1876(\mathrm{~S})$ & $\begin{array}{c}0.77 \pm 0.39 \\
(0.63)\end{array}$ & $\begin{array}{c}0.68 \pm 0.25 \\
(0.60)\end{array}$ & $\begin{array}{c}0.87 \pm 0.90 \\
(0.55) \\
\end{array}$ \\
\hline $\begin{array}{l}\text { C10 } \\
(123.0-125.0)\end{array}$ & $<1832-1850(\mathrm{~S})$ & $\begin{array}{l}0.74 \pm 0.23 \\
(0.69)\end{array}$ & $\begin{array}{l}0.74 \pm 0.23 \\
(0.69)\end{array}$ & $\begin{array}{c}0.13 \pm 0.10 \\
(0.09)\end{array}$ \\
\hline $\begin{array}{l}\text { CDK basal } \\
(119.2-121.0)\end{array}$ & $1090-1390(\mathrm{~S})$ & $\begin{array}{l}0.70 \pm 0.07 \\
(0.70)\end{array}$ & $\begin{array}{l}0.70 \pm 0.07 \\
(0.70)\end{array}$ & $\begin{array}{c}0.09 \pm 0.03 \\
(0.09)\end{array}$ \\
\hline $\begin{array}{l}\text { CDK basal } \\
(121.8-122.0 \\
122.7-122.9)\end{array}$ & $\begin{array}{l}\text { Pre- and post-Roman } \\
(1000-600 \mathrm{BCE} \\
400-600 \mathrm{CE})(\mathrm{S})\end{array}$ & $\begin{array}{l}0.73 \pm 0.06 \\
\quad(0.72)\end{array}$ & $\begin{array}{l}0.73 \pm 0.06 \\
\quad(0.72)\end{array}$ & $\begin{array}{l}0.027 \pm 0.01 \\
(0.025)\end{array}$ \\
\hline $\begin{array}{l}\text { C10 } \\
(120.53-120.97 ; \\
121.80-122.10)\end{array}$ & $<1858-1870(\mathrm{~W})$ & $\begin{array}{l}0.36 \pm 0.09 \\
\quad(0.35)\end{array}$ & $\begin{array}{l}0.36 \pm 0.09 \\
\quad(0.35)\end{array}$ & $\begin{array}{l}0.08 \pm 0.06 \\
\quad(0.05)\end{array}$ \\
\hline
\end{tabular}

Table 1. Change through time of CDD ice concentrations of total bromine (Brred2 values were here considered, see section 4.1), bromine related to leaded-gasoline aerosol $\left(\mathrm{PbBrCl}^{*}\right)$ and nonrelated to leaded-gasoline (Bry*), and non-crustal $\mathrm{Pb}(\mathrm{ncPb})$. All concentrations are in $\mathrm{ng} \mathrm{g}^{-1}$. Values under parenthesis reported for $\mathrm{PbBrCl}^{*}$ and $\mathrm{Bry}^{*}$ refer to minimum and maximum concentrations obtained when using a $\mathrm{Br} / \mathrm{Pb}$ ratio of 0.386 and 0.27 (see text).

\begin{tabular}{|l|c|c|c|c|c|c|}
\hline Species & $\begin{array}{c}1930-50 \\
\text { Summer }\end{array}$ & $\begin{array}{c}1965-80 \\
\text { Summer }\end{array}$ & $\begin{array}{c}1990-2000 \\
\text { Summer }\end{array}$ & $\begin{array}{c}1930-50 \\
\text { Winter }\end{array}$ & $\begin{array}{c}1965-80 \\
\text { Winter }\end{array}$ & $\begin{array}{c}1990-2000 \\
\text { Winter }\end{array}$ \\
\hline $\mathrm{Br}$ & 0.69 & 1.37 & 1.14 & 0.33 & 0.50 & 0.50 \\
\hline $\mathrm{PbBrCl}^{*}$ & 0.03 & 0.525 & 0.15 & 0.00 & 0.05 & 0.013 \\
& $(0.024-0.034)$ & $(0.44-0.61)$ & $(0.12-0.15)$ & $(\mathrm{a}-\mathrm{a})$ & $(0.04-0.05)$ & $(\mathrm{a}-\mathrm{a})$ \\
\hline $\mathrm{Bry} *$ & 0.66 & 0.85 & 0.99 & 0.32 & 0.45 & 0.49 \\
& $(\mathrm{a}-\mathrm{a})$ & $(0.76-0.94)$ & $(0.97-1.02)$ & $(0.32-0.32)$ & $(0.44-0.46)$ & $(0.49-0.49)$ \\
\hline $\mathrm{ncPb}$ & 0.97 & 2.27 & 0.66 & 0.15 & 0.31 & 0.07 \\
\hline
\end{tabular}

\section{2}


Figure 1. 


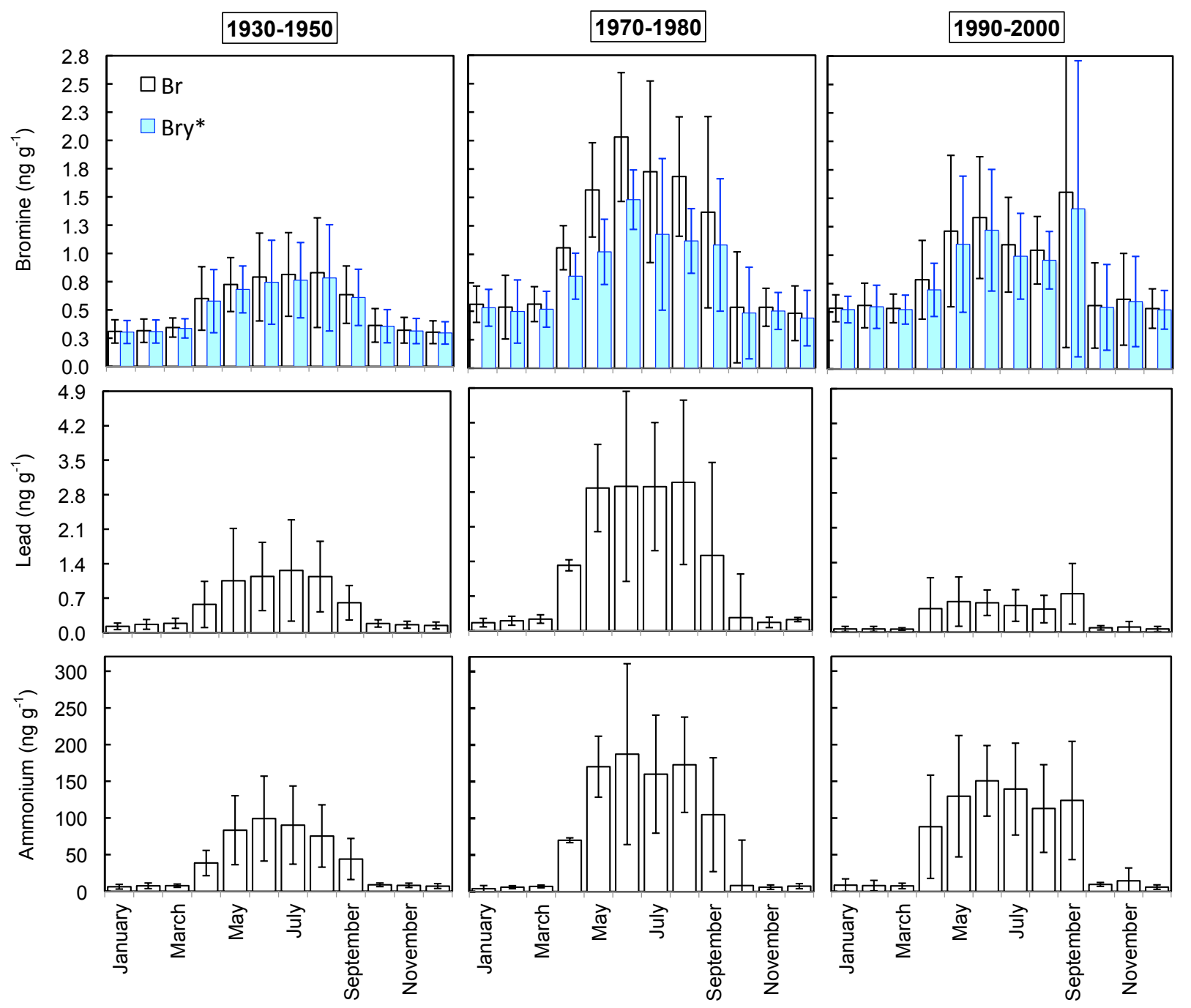


Figure 2. 


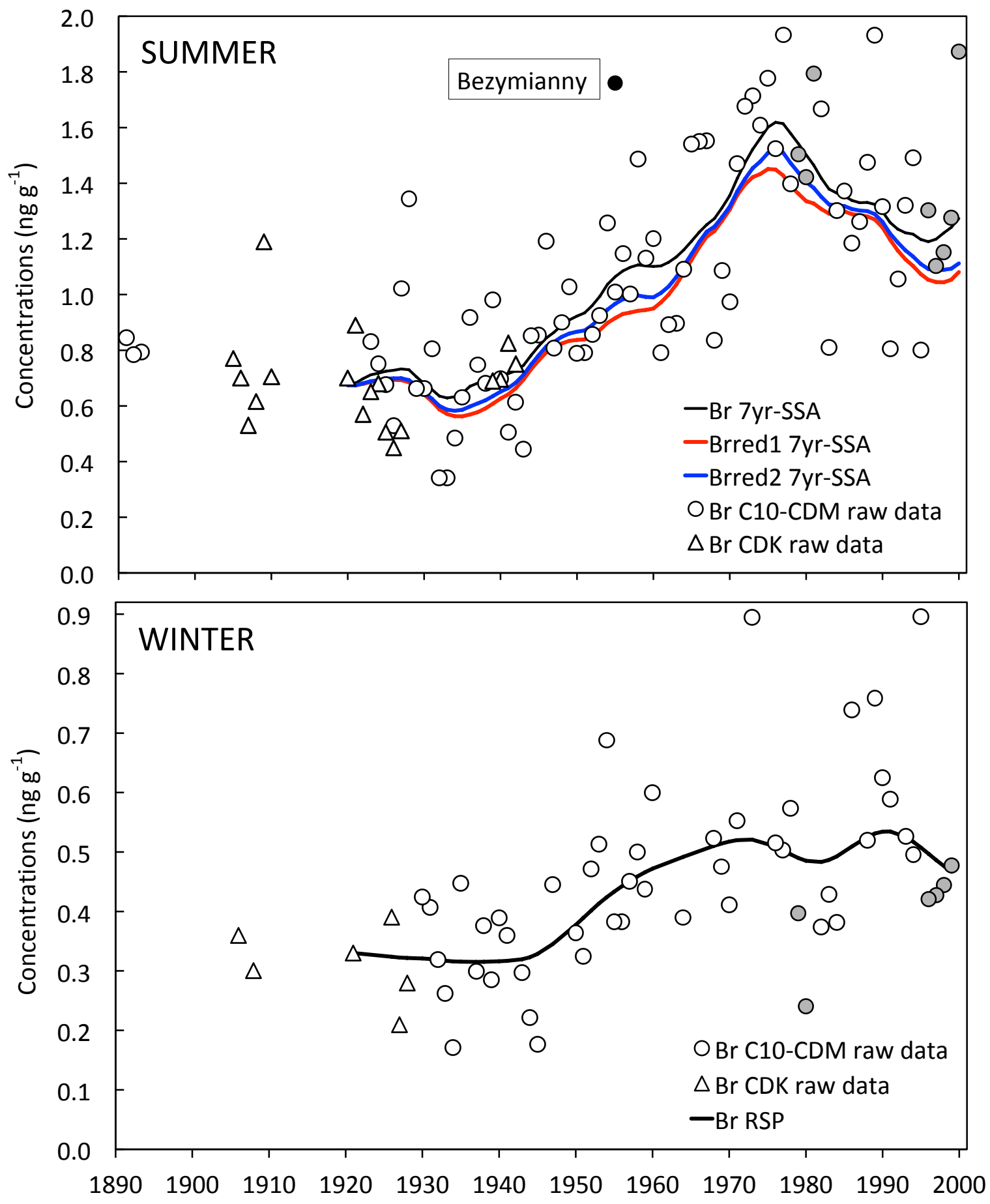


Figure 3. 


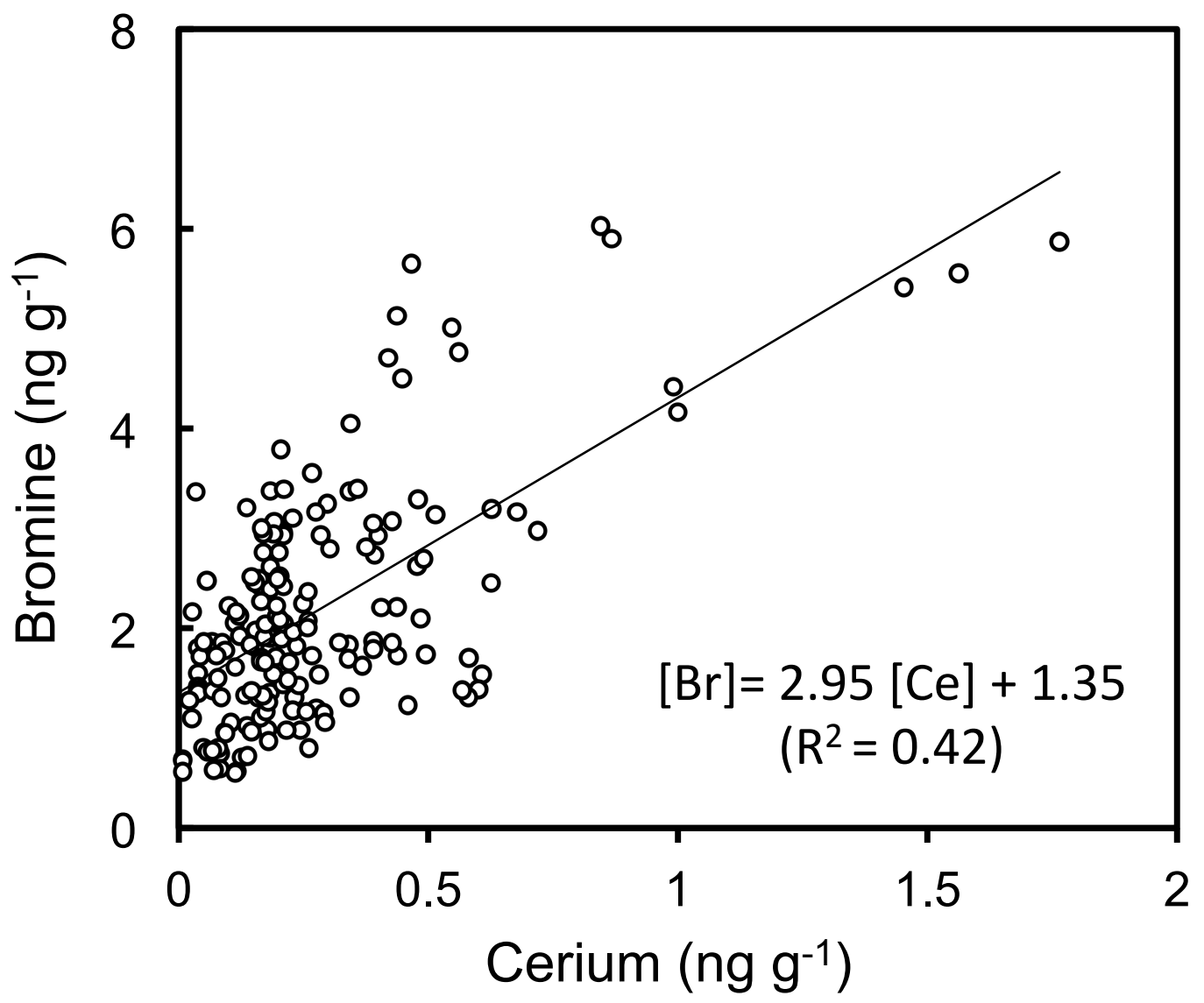


Figure 4. 


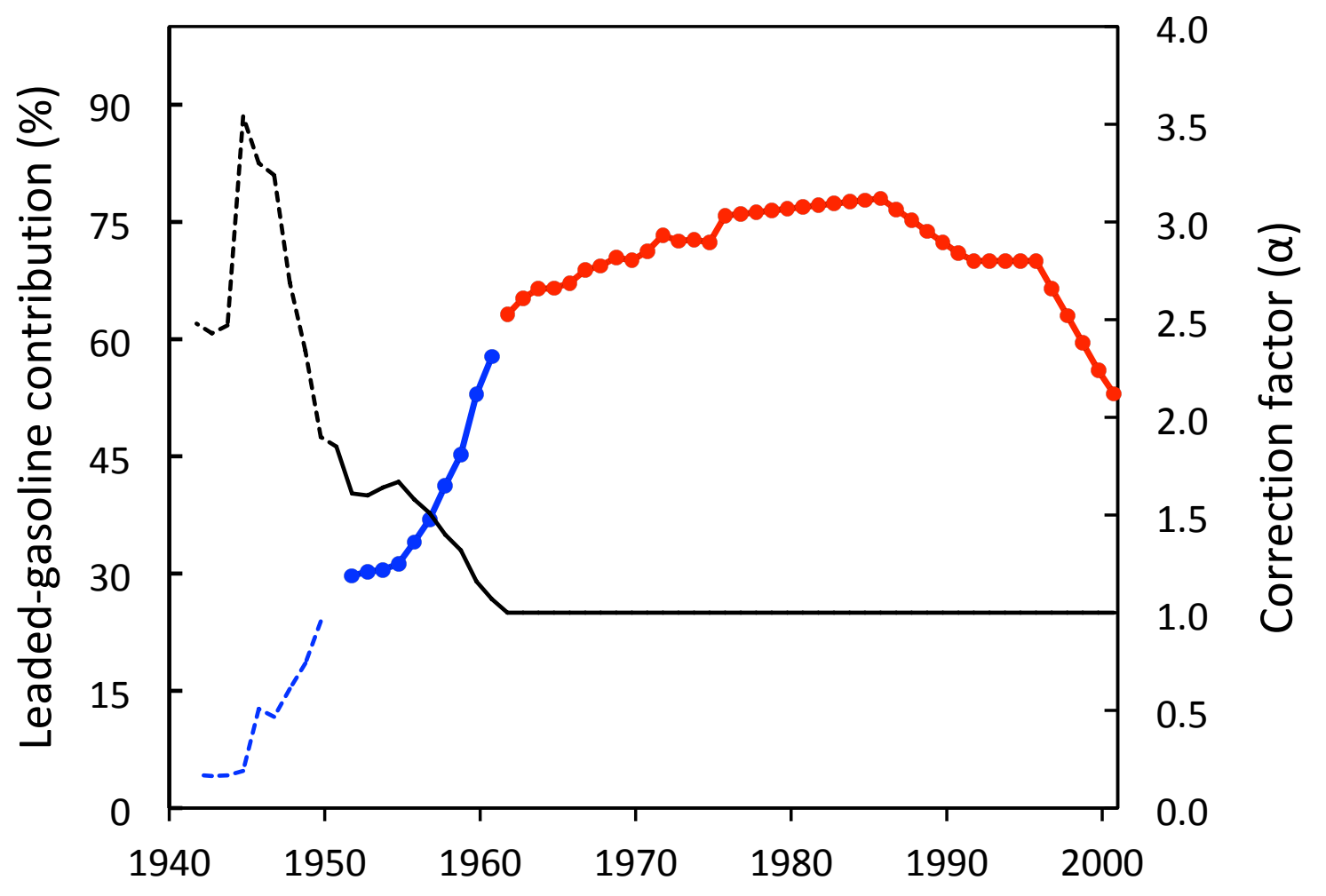


Figure 5. 

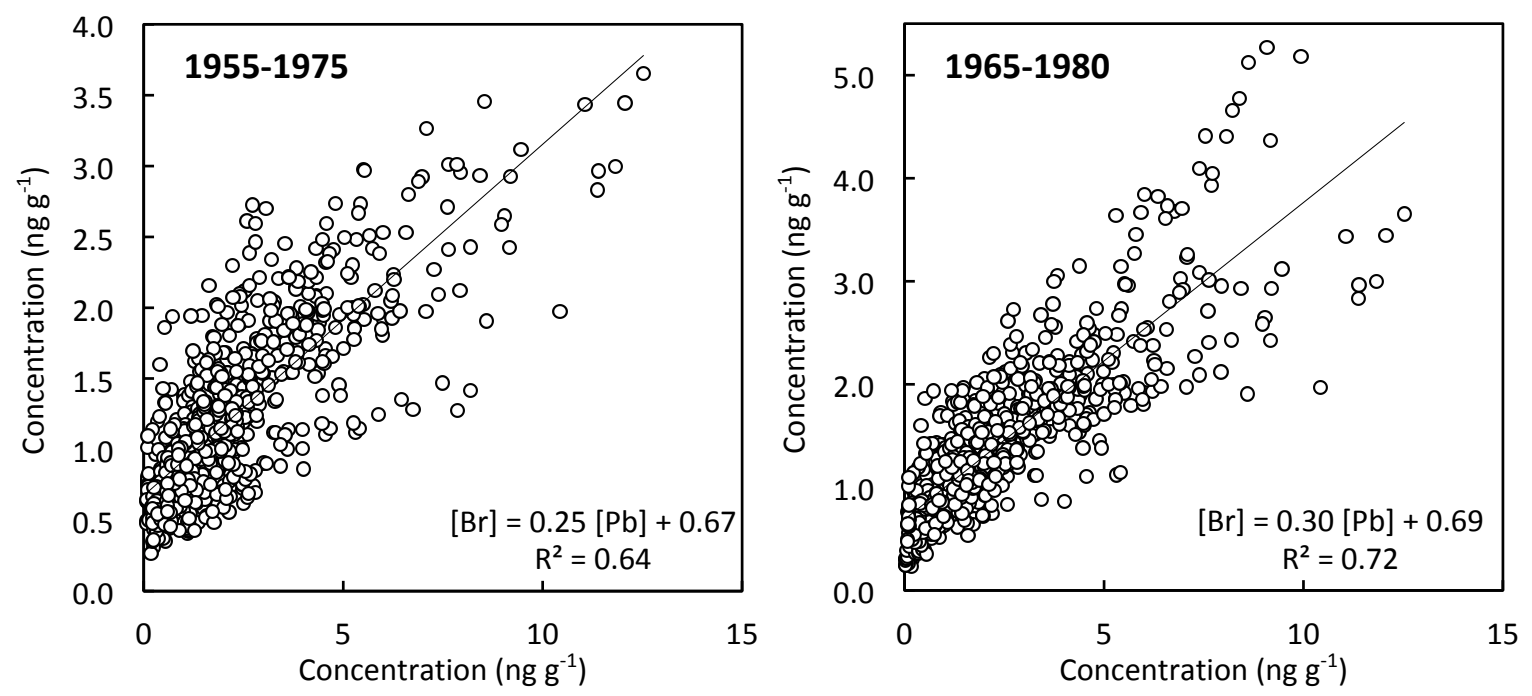
Figure 6. 


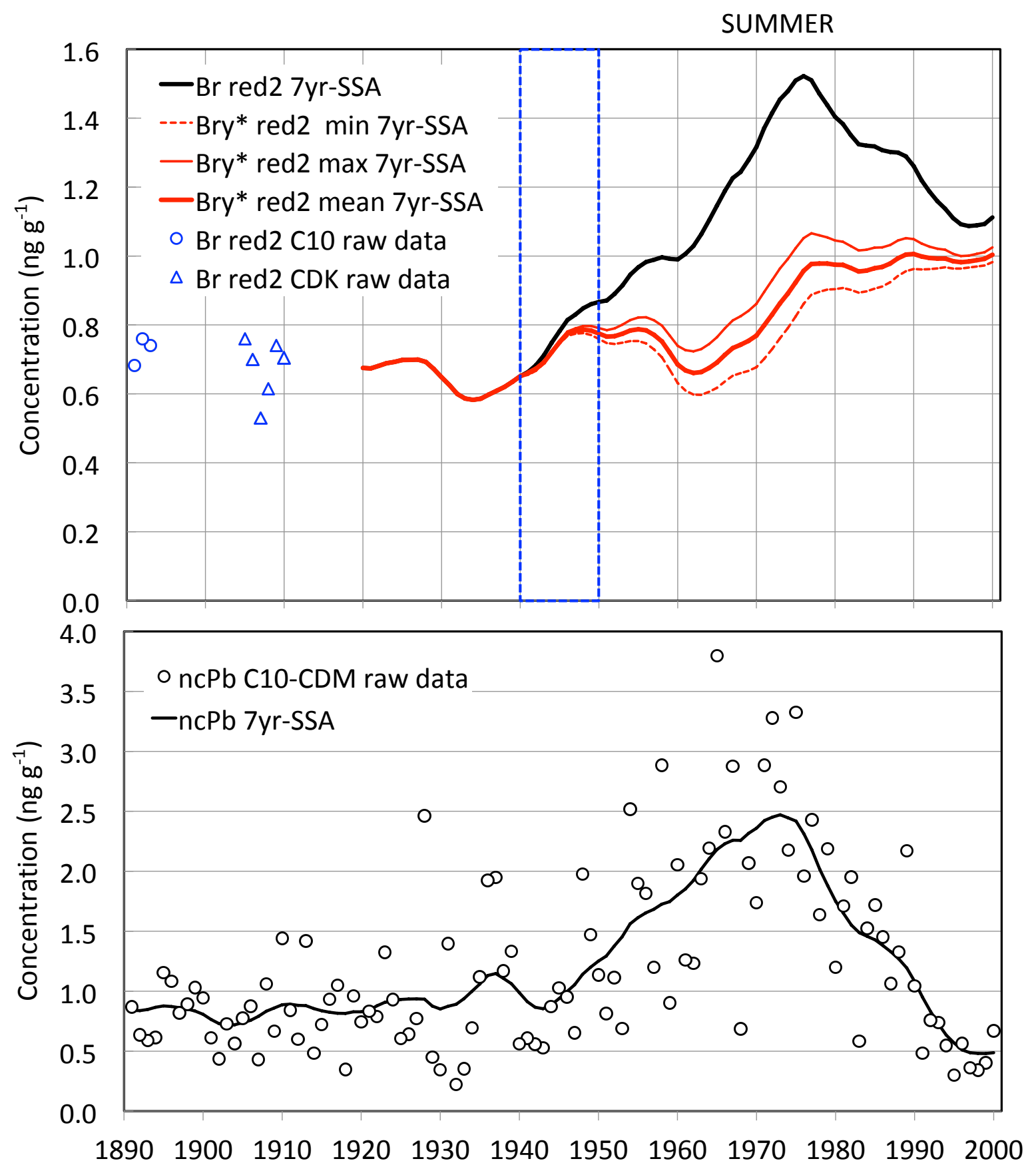


Figure 7. 


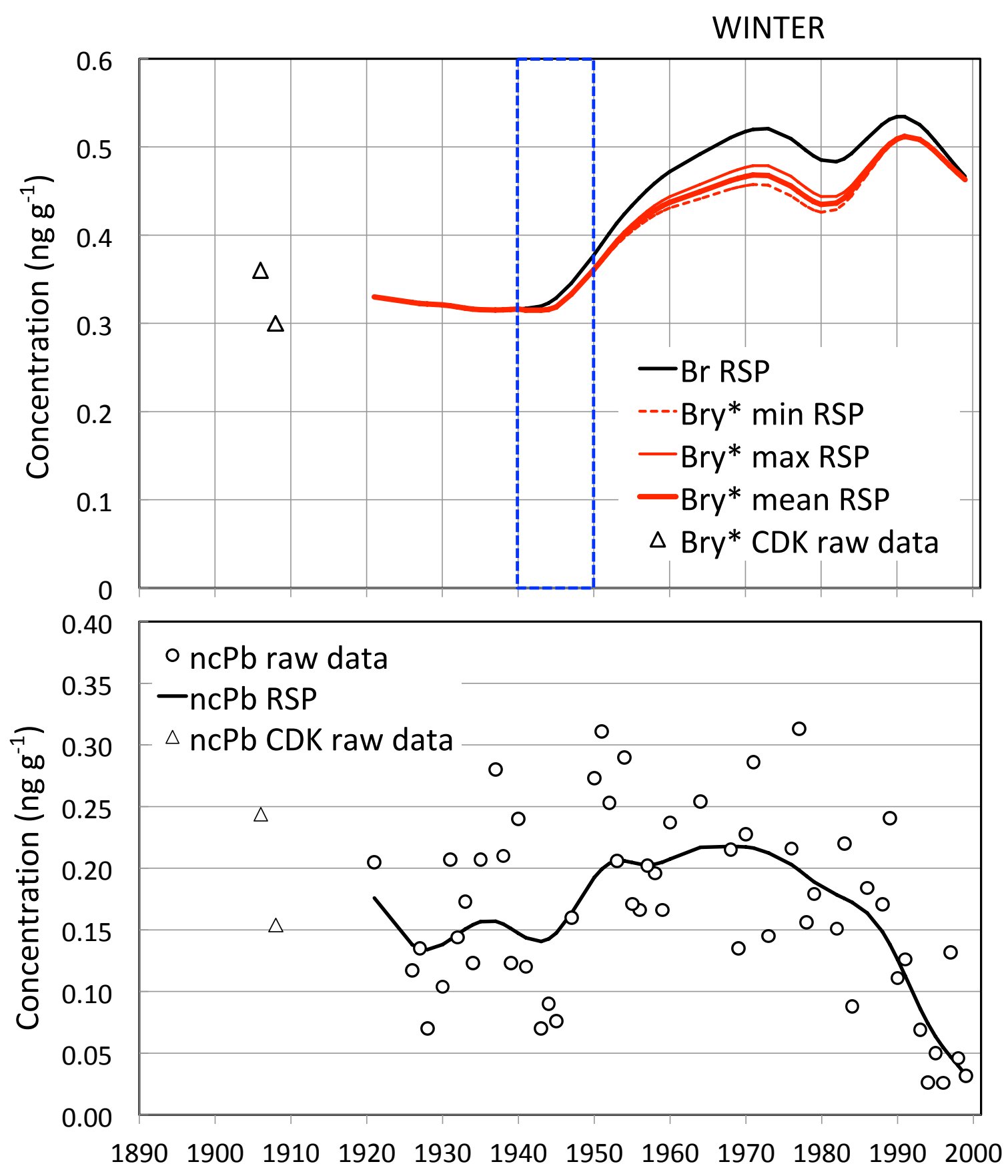

